\title{
The paradox of openness revisited: Collaborative innovation and patenting by UK innovators
}

\author{
Ashish Arora $^{\mathrm{a}, \mathrm{b}}$, Suma Athreye ${ }^{\mathrm{c}}$, Can Huang ${ }^{\mathrm{d}, *}$ \\ a Fuqua School of Business, Duke University, 100 Fuqua Drive, Durham, NC 27708-0120, USA \\ b National Bureau of Economic Research, Boston, MA, USA \\ ${ }^{c}$ Brunel Business School, Brunel University, Uxbridge, UB8 3PH, United Kingdom \\ ${ }^{\mathrm{d}}$ Institute for Intellectual Property Management, School of Management, Zhejiang University, Yuhangtang Road 866, Hangzhou, Zhejiang Province 310058, \\ PR China
}

\section{A R T I C L E I N F O}

\section{Article history:}

Received 8 May 2014

Accepted 13 January 2016

Available online 11 April 2016

\section{Keywords:}

Open innovation

Patent use

Patent

External knowledge source

Community innovation survey

\begin{abstract}
A B S T R A C T
We revisit the "paradox of openness" in the literature which consists of two conflicting views on the link between patenting and open innovation-the spillover prevention and the organizational openness views. We use the data from the Survey of Innovation and Patent Use and the Community Innovation Survey (CIS6) in the UK to assess the empirical support for the distinct predictions of these theories. We argue that both patenting and external sourcing (openness) are jointly-determined decisions made by firms. Their relationship is contingent upon whether the firms are technically superior to their rivals and lead in the market or not. Leading firms are more vulnerable to unintended knowledge spillovers during collaboration as compared to followers, and consequently, the increase in patenting due to openness is higher for leaders than for followers. We develop a simple framework that allows us to formally derive the empirical implications of this hypothesis and test it by estimating whether the reduced form relationship between patenting and collaboration is stronger for leaders than for followers.
\end{abstract}

(c) 2016 The Authors. Published by Elsevier B.V. This is an open access article under the CC BY license. (http://creativecommons.org/licenses/by/4.0/)

\section{Introduction}

Over the last quarter century two apparently contrasting trends have marked the innovation process. On the one hand, patents have become increasingly important as an appropriation tool (OECD, 2004; WIPO, 2007). On the other, innovators are increasingly relying upon collaboration with other firms and organizations (Chesbrough, 2003). The question we address in this paper is the relationship between sourcing knowledge from the outside to

\footnotetext{
it This research was funded by a ESRC grant (ES/K000756/1) with matched funding from the UKIPO. The views expressed in this paper represent the views of the authors and not the UK IPO. Can Huang is grateful for the financial support of the National Natural Science Foundation of China Grant No. 71402161. The authors are grateful to Tony Clayton, Ray Lambert and Peter Evans who contributed to the design of the survey instrument used to collect data on innovation and patent use. We also wish to thank the Office for National Statistics for delivering a high quality survey. In particular we acknowledge the efforts of the interviewers in the ONS telephone unit. The UK CIS data used in this paper are Crown Copyright and made available to us by the IPO and BIS. The usual disclaimer applies.

* Corresponding author.

E-mail addresses: ashish.arora@duke.edu (A. Arora),suma.athreye@brunel.ac.uk (S. Athreye), canhuang@zju.edu.cn (C. Huang).
}

develop innovations and using patents to appropriate the returns from innovation. ${ }^{1}$

The relationship between the reliance on external sources and the appropriability strategy of firms has been analysed extensively since the early paper by Cassiman and Veugelers (2002). This literature has converged around two conflicting points of view, which Laursen and Salter (2014) dub the "paradox of openness", namely that opening up to outside sources of knowledge to innovate may weaken the firm's power to capture rents from that knowledge. In other words, openness, or external sourcing, entails a trade-off. On the one hand, firms are more likely to seek external collaborators if they can protect their innovation by patents, and more generally, guard against unintended knowledge spillovers to partners. We call this the "spillover prevention" view. The second view, which we call "organizational openness", holds that a focus on patenting and exclusivity makes a firm less efficient in developing collaborative innovations, and hence also, a less attractive partner.

Our paper advances the debate on openness versus patenting in several ways. First, we argue in this paper that the relationship

\footnotetext{
1 There is an older and even more extensive literature on the importance of patents for selling or licensing technology (Arrow, 1962; Arora et al., 2001; Gans et al., 2008). See also Arora and Gambardella (2010) for a survey of the literature.
} 
between external sourcing (openness) and patenting is contingent. Firms will make different choices depending upon whether they are technically superior to their rivals and lead in the market or not. Put differently, the trade-off between appropriating benefits and enhancing the efficiency of collaboration differs between leaders and followers. Leading firms are more vulnerable to unintended knowledge spillovers during collaboration as compared to followers, and consequently, the increase in patenting due to openness is higher for leaders than for followers. We test this by estimating whether the reduced form relationship between patenting and collaboration is stronger for leaders than for followers.

Second, we advance the literature by treating both patenting and openness as choices made by the firm, and therefore, as jointly determined endogenous variables. The existing literature has treated either openness as logically prior to appropriability (e.g., Laursen and Salter, 2014) or appropriability as logically prior (e.g., Zobel et al., 2013). We develop a simple framework that provides a useful way to link the underlying theories based on the costs and benefits of collaborative innovation to the observed relationship between patenting and openness. Instead of interpreting our results as causal relationships, we treat them as describing the patterns of association between patenting and openness, and use our framework to infer what these patterns imply for various theories, and how this varies between leaders and followers.

Our third contribution is to introduce new and more precise measures of the use of patents based upon a new survey, instead of relying upon perceived importance of various appropriability strategies as much of the existing literature has done. Our data are based on a survey of over 800 UK firms using the sixth wave of the Community Innovation Survey (CIS 6). We are able to augment our data by also using the responses of these firms in the CIS 6 .

The remainder of this paper is organised in the following way: Section 2 surveys the relevant literature on the paradox of openness and highlights the issues that limit the empirical analysis in this area. Section 3 articulates why leaders face a different tradeoff from followers, and provides a simple model of the benefits and costs of openness that links the theoretical trade-off to behaviour, which motivates our empirical analysis. Section 4 introduces the data and describes our key measures. Section 5 discusses the empirical results. Section 6 concludes.

\section{Openness and appropriability}

\subsection{Theoretical views}

There are two dominant views on how patenting is related to use of external knowledge sources in innovation - we call these the "spillover prevention" theory and the "organizational openness" theory.

In the "spillover prevention" theory (Cassiman and Veugelers, 2002) firms engaged in outside collaboration favour the use of patents as a means of reducing spillovers of valuable knowledge to external partners. In the simplest version of the spillover theory, firms want to prevent imitation of their (focal) innovation and patent in order to protect the rents from that innovation. The likelihood of spillovers is greater if the firm is open i.e., if it collaborates with a partner, because collaboration inevitably reveals more information to others than if the innovation were entirely in-house.

It is widely recognized that using external knowledge could make it more difficult to protect the innovation. For instance, Noordhoff et al. (2011) argue that innovations sourced from customers carry the risk that the customer may implement the invention itself, in effect becoming a competitor. Giarratana and Mariani (2014) argue that using outside sources of knowledge makes it harder to enforce secrecy within the firm, increasing the risk of imitation. Consequently, if a firm is unwilling to patent, or if patents are ineffective, it may choose to be closed. The key takeaway is that a firm has a greater incentive to patent if it is open than if it is closed. Simply put, in this view, we expect to see a positive association between patenting and openness.

Protecting the focal innovation is not the only source of positive association between patenting and openness. Many innovations are complex and require prior knowledge or background knowledge. Crucial bits of background information can leak out to partners during collaboration. Patents can protect against leakage of background material as well. Arora and Merges (2004) develop an analytical model in which the fear of knowledge spillovers may lead firms to internalize research even if internal research is less productive than external research, and the patents condition this trade-off. Using firm-level data from Germany, Buss and Peukert (2015) document a positive link between $R \& D$ outsourcing and intellectual property infringement, particularly for generic knowledge.

More broadly, scholars have argued that strong IPRs are often beneficial and potentially even necessary for open innovation (Arora and Gambardella, 1994; Chesbrough, 2003). Thus, Graham and Mowery (2006) suggest that “... IP protection creates a platform for the transfer of knowledge assets..." (p.185). Note that Arora and Gambardella (1994) and Graham and Mowery (2006) have focused on the importance of IP protection to the agent transferring knowledge rather than sourcing it, whereas this paper is focused on firms sourcing external knowledge.

A different source of positive association between patenting and openness is that open firms may patent to signal their innovative capabilities to other firms (Alexy et al., 2009; Hagedoorn and Ridder, 2012). For instance, Hagedoorn and Ridder (2012) surveyed 86 firms which are active in open innovation and found that nearly $90 \%$ of the firms regard patent as important method for signaling the nature of their technological capabilities.

In sum, firms that rely on external sources of knowledge (open firms) will patent much more than firms that do not (closed firms) for three reasons. First, they want to protect their focal innovation produced through collaboration; second, they want to protect the background knowledge implicit in the innovation; and third, they want to send out precise signals about their value as innovation partners.

By contrast, the "organizational openness" theory, inspired partly by studies of open-source software and the literature on "collective invention" (cf. Allen, 1983; Bessen and Nuvolari, 2012), implies that firms engaged in external collaboration should be less likely to use patents. Laursen and Salter (2014) note that a focus on patenting may make it harder to collaborate with outsiders. For instance, Foss et al. (2011) show that in order to benefit from customer interactions, firms have to delegate responsibility and increase internal communication. An unintended consequence may be that proprietary information can spill out. In other words, a focus on protecting the firm's proprietary information is likely to make it more difficult to collaborate with outsiders. Other scholars have also stressed the tension between IPR and openness to outside knowledge. Jensen and Webster (2009) contend that knowledge capture practices may impede collaborative knowledge creation process. For example, interacting with other organizations to stimulate knowledge creation relies on interdependencies and reciprocities, whereas patenting gives rise to exclusivity. The emphasis on exclusivity that a patenting intensive appropriation strategy entails can impede the efficiency of collaborative development of innovation.

Interestingly, even those who believe that open innovation is often facilitated by strong intellectual property rights (IPR), concede that firms may benefit from voluntarily waiving some of their intellectual property rights (Chesbrough and Appleyard, 2007; Pisano, 2006). The strategy that firms choose to purposefully disclose selected knowledge to general public (including competitors), 
instead of keeping them proprietary, is termed as "selective revealing" (Henkel, 2006; Henkel et al., 2014; Alexy et al., 2013). ${ }^{2}$ By engaging in selective revealing, a focal firm can encourage others to participate in shared problems solving or to make complementary investments (Alexy et al., 2013). In other words, patenting and associated secrecy can make a firm a less attractive partner to potential collaborators. Thus, the organizational openness view would posit that firms that seek external knowledge for innovation are less likely to patent because patenting impedes their ability to gain from collaboration, and because they want to be attractive partners for potential collaborators.

To summarize, the literature on openness and appropriability has stressed different aspects of the tradeoff. The empirical literature has also documented a variety of findings. Some studies find a positive relationship between appropriability and openness. For instance, Cassiman and Veugelers (2002) use data on Belgian innovators from the European Community Innovation Survey (CIS) to test how firms fashion their appropriation strategy to guard against spillover of knowledge in formal R\&D collaborations. They find that the reported effectiveness of "strategic appropriation" (secrecy, complexity, lead-time) is positively related to the probability of external collaboration, but also that the probability of external collaboration is not related to the effectiveness of intellectualproperty protection (patents, trademarks, and copyrights). Zobel et al. (2013) find that patenting is positively associated with different types of external collaborations for a sample of solar technology start-ups in the U.S.

Other scholars report opposite findings. Based on the survey data of 785 Australian firms, Jensen and Webster (2009) conclude that the firms favoring internal R\&D and relying upon secrecy and patenting are less likely exchange of knowledge with partners. When firms do use external knowledge, they rely on licensing, hiring other organizations' workers, and public domain sources such as patent disclosures, publications and technical meetings. Firms that rely upon external knowledge operate in the opposite manner: They are less likely to use patenting and secrecy and collaborate with suppliers, customers, and other partners. Alexy et al. (2014) do not report the direct relationship between patenting and openness, but their results indicate that patenting intensive firms are less likely to be open, particularly when they are underperforming.

Other studies report intermediate findings. For instance, Arundel (2001) analyses the data of the 1993 European Community Innovation Survey for up to 2849 R\&D-performing firms, and finds only weak evidence that participation in cooperative R\&D increases the value of patents over secrecy for product innovations. Laursen and Salter (2014), using data on over 2900 innovators from the 4th UK community Innovation Survey, find that openness first increases and then decreases with an emphasis on appropriability. Huang et al. (2014) use data from a 2003 survey of over 4000 Australian firms. They too find that the degree of openness is non-linearly related to appropriability. However, when they restrict attention to formal appropriability (patents, copyrights and trademarks), they find a positive relationship between appropriability and openness. Arora et al. (2014), using data on nearly 1500 American manufacturing firms, finds that there is no systematic difference on average between firms that used external inventions versus those that used internal inventions. However, they also find

\footnotetext{
2 Practices similar to selective revealing have long existed and can be found in historical accounts. Allen (1983) documents how the sharing of information among competitors in the English blast furnaces industry in 1850-1875 contributed to the innovation and development of the industry. Nuvolari (2004) also studies the collective invention settings in the Cornish mining district in the early period of industrialization, which contributed to the development of one of the key technologies of that period, steam power.
}

that firms that relied upon customers and suppliers for inventions were less likely to patent the focal invention than firms that relied upon internal invention, whereas firms that used inventions from universities, independent inventors and R\&D suppliers were more likely to patent the focal invention.

\subsection{Econometric and measurement challenges}

The empirical literature on openness and appropriability suffers from some shortcomings. Many studies have tended to use measures of appropriability in general, often because specific information on patent use is difficult to obtain. ${ }^{3}$ Yet, the use of patents is fundamentally different from other types of appropriability strategies such as secrecy, first mover advantage or product complexity. For instance, collaboration will surely weaken the ability of the firm to keep secrets. Indeed, Arundel (2001) reports that openness is associated with a greater importance of patenting relative to secrecy. Similarly, knowledge itself is "non-rival" in use. Consequently, both partners can use it, reducing the chances of conflict, unless one partner wishes to patent it. Thus, Huang et al. (2014) find different results when they focus on formal versus informal appropriability. By focusing on a widely studied means of appropriability, namely patenting, we hope to sharpen our understanding of this complex topic.

Another shortcoming is the use of the reported effectiveness of patents as perceived by the respondent rather than actual use of appropriation methods to protect innovations. Perceived effectiveness scores are problematic. Though ordinal, they are typically treated as cardinal variables in regressions. Perhaps even more problematic is that they are not easy to compare across respondents. Many, but not all, of the studies cited above, including Arundel (2001), Cassiman and Veugelers (2002), Laursen and Salter (2014), and Huang et al. (2014), use ordinal scaled measures of the importance of appropriability mechanisms, which are then aggregated in a variety of ways.

Actual measures of patenting intensity of innovations can overcome this limitation but are not commonly used. ${ }^{4}$ Pérez-Luño and Valle-Cabrera (2011), Cohen et al. (2000), Alexy et al. (2014) ask innovating firms about their use of patenting in general (specifically, the percentage of their innovations for which they had applied for patents), but Arora et al. (2014) ask respondents whether they had patented their most significant innovation-the innovation that accounted for a plurality of their sales-over the last three years. In our empirical analysis, we feature the latter measure, namely whether the firm has patented its most significant innovation. We find similar, though weaker, results using the share of innovations protected by patents.

Lastly, the empirical literature has treated the trade-off between appropriability (patenting) and openness as a causal relationship (e.g., Cassiman and Veugelers, 2002; Laursen and Salter, 2014; Huang et al., 2014; Alexy et al., 2013; Zobel et al., 2013). ${ }^{5}$ This is problematic because both patenting and openness are strategic choices by the firm and it is difficult to assign logical priority.

\footnotetext{
${ }^{3}$ For instance, Laursen and Salter (2014) do not distinguish between formal appropriation mechanisms such as patents, and appropriation via secrecy or leadtime, Cassiman and Veugelers (2002) divide appropriation strategy into formal appropriation strategies (which include patents, but also trademarks and copyrights) and other types of appropriation strategies.

${ }^{4}$ Earlier rounds of CIS typically lacked information on actual use. In some instances, all that was asked was whether the firm had patented or not, without normalizing by the scale of innovation activity. The latest UK CIS does ask for actual share of innovations protected by the different methods of appropriability.

${ }^{5}$ In some cases, scholars (e.g., Huang et al., 2014) have compounded the problem by not distinguishing between firms that successfully innovate and those that do not. It is likely that firms that do not innovate are less likely to patent and also less likely to report external collaborations.
} 
Empirically, this requires instruments for the endogenous choice, a difficult task which the literature has rarely undertaken successfully. This problem can however be sidestepped because theory does not prescribe causality. Instead it prescribes patterns of association. An example of such an approach is Buss and Peukert (2015), who eschew causal estimation and instead use reduced form estimation to show that R\&D outsourcing is associated with higher likelihood of product infringement.

Further, as developed more fully in the next section, the association between openness and patent use will differ in strength, and perhaps also in direction, across different types of firms. Firms have heterogeneous abilities but there is little attempt in the empirical literature to distinguish between the different types of firms-such as firms which are technology leaders and those that are technology followers. In other contexts where technological leakages may pose a strategic threat or advantage, scholars have emphasised the different costs of collaboration to leaders and followers. For example, writing about agglomeration economies, regional spillovers and MNE location, Alcácer and Chung (2014) and Chung and Alcacer (2002) find technology leaders care more about accessing scientific resources from locations while technology followers are likely to position themselves to profit from locating in areas where spillovers are prevalent. Agglomerations thus mainly attract technology followers that hope to benefit from spillovers while technology leaders are more likely to pursue specialised scientific assets.

\section{Leaders, followers and the paradox of openness revisited}

The tradeoff between openness and appropriation is contingent upon the type of firm. Specifically, the association between patenting and openness will be stronger when the focal firm invests heavily in research and development, and relies upon product innovation, because such a firm is more vulnerable to spillovers during collaboration. Such firms will have proprietary technical information which distinguishes them from rivals. Their profits are also more sensitive to the entry of imitators, which erode innovation rents. These firms, whom we call leaders, are more likely to benefit from patents if they are open, as compared to followers, who have less to gain from patenting, and potentially more to gain from successfully collaborating. Followers have less proprietary technical information. They also typically have less to fear that their spillovers will facilitate the entry of other competitors. As a result, their benefits from patenting should be less closely related to whether they are open or not, as compared to leaders.

To express this intuition more precisely, we develop a framework which makes explicit the costs and benefits of both openness and patenting and recognises that firms make decisions on patenting and openness at the same time. Let $\mathrm{V}$ be the value from the innovation without collaboration and $(\mathrm{V}+\mathrm{x}+\mathrm{y})$ be the value with collaboration. We assume $x>0$ which is the same as assuming that collaboration creates value. When there is a potential for spillovers, the value with collaboration will include an additional term, $\mathrm{y}$, which y represents leakage of knowledge. We assume that spillovers reduce value i.e., $\mathrm{y}<0$. Thus $\mathrm{x}+\mathrm{y}$ represents the net incremental profit from collaborating during innovation.

Patenting offers firms an opportunity to reduce leakage losses during collaboration and, independent of collaboration, potentially also increases the value of the innovation by preventing imitation. For a closed firm, let $\mathrm{V}^{\mathrm{p}}$ be the payoff from innovation with a patent, and $\mathrm{V}^{\prime}=\mathrm{V}^{\mathrm{P}}-\mathrm{V}$ represent the change in value if firm patents. Similarly, for an open firm, the payoff it patents is $\mathrm{V}^{\mathrm{p}}+\mathrm{x}^{\mathrm{p}}+\mathrm{y}^{\mathrm{p}}$, where $\mathrm{x}^{\mathrm{p}}$ represents the benefit of collaboration with a patent, and $\mathrm{y}^{\mathrm{p}}$ represents the loss of value due to leakage of information protected by a patent. Thus $\mathrm{x}^{\prime}=\mathrm{x}^{\mathrm{p}}-\mathrm{x}$ represents how the incremental value from collaboration changes if the firm patents. Similarly $y^{\prime}=y^{p}-y$ represents the reduction in value loss due to leakage of valuable information, either about the focal innovation or background knowledge.

Note that $\mathrm{V}^{\prime}$ represents the "traditional" motive for patenting, namely to protect the focal innovation. Not all innovations can be patented. Moreover, an innovation may not be worth patenting, once the direct costs of obtaining a patent and the indirect costs, in the form of disclosure, are taken into account. Therefore, $\mathrm{V}^{\prime}$ can be either positive or negative.

One can interpret $\mathrm{x}^{\prime}$ as representing the potential inefficiency in collaboration when the partners are trying to collaborate but one is focused on patenting. Organisational-openness theory implies $\mathrm{x}^{\prime}<0$ because patenting reduces the value from collaboration. Finally, $\mathrm{y}^{\prime}$ represents the potential benefit from patenting to guard against spillovers during collaboration, and the spilloverprevention theory implies $y^{\prime}>0$. The sum, $x^{\prime}+y^{\prime}$, represents the difference in the incremental payoff to patenting between open and closed firms.

Since patenting and openness are not randomly assigned to firms but jointly determined, moving from theoretical trade-offs to observed combinations of choices depends not only on the payoff to that choice but also the payoffs of all other choices. Using the notation developed above, we can specify four combinations, along with the associated payoffs - (i) collaborate and patent $\left(\mathrm{V}^{\mathrm{p}}+\mathrm{x}^{\mathrm{p}}+\mathrm{y}^{\mathrm{p}}\right)$; (ii) collaborate and not patent $(\mathrm{V}+\mathrm{x}+\mathrm{y})$; (iii) not collaborate and patent $\left(\mathrm{V}^{\mathrm{P}}\right)$; and not collaborate and not patent $(\mathrm{V})$. If we assume that the payoff from each choice has an additive error term that is iid and distributed with a Generalized Extreme Value (GEV) distribution, the probability of the different combination of choices can be written as follows ${ }^{6}$

$\operatorname{Pr}($ nocollaborate\&nopatent $)=\exp (V) / D$

$\operatorname{Pr}($ nocollaborate\&patent $)=\exp \left(\mathrm{V}^{\mathrm{p}}\right) / \mathrm{D}$

$\operatorname{Pr}($ collaborate\&nopatent $)=\exp (\mathrm{V}+\mathrm{x}+\mathrm{y}) / \mathrm{D}$

$\operatorname{Pr}($ collaborate\&patent $)=\exp \left(\mathrm{V}^{\mathrm{p}}+\mathrm{x}^{\mathrm{p}}+\mathrm{y}^{\mathrm{p}}\right) / \mathrm{D}$

Where $\mathrm{D}=\exp (\mathrm{V})+\exp \left(\mathrm{V}^{\mathrm{p}}\right)+\exp (\mathrm{V}+\mathrm{x}+\mathrm{y})+\exp \left(\mathrm{V}^{\mathrm{p}}+\mathrm{x}^{\mathrm{p}}+\mathrm{y}^{\mathrm{p}}\right)$

Notice that the joint probability given in (4) is related to but different from the probability of collaboration given patenting-the focus of much of the empirical literature. In fact there are four conditional probabilities we could derive and they are given by:

$$
\begin{aligned}
& \operatorname{Pr}(\text { collaboration|patent })=\exp \left(\mathrm{V}^{\mathrm{p}}+\mathrm{x}^{\mathrm{p}}+\mathrm{y}^{\mathrm{p}}-\mathrm{V}^{\mathrm{p}}\right) / \\
& \quad\left(1+\exp \left(\mathrm{V}^{\mathrm{p}}+\mathrm{x}^{\mathrm{p}}+\mathrm{y}^{\mathrm{p}}-\mathrm{V}\right)\right)=\exp \left(\mathrm{x}^{\mathrm{p}}+\mathrm{y}^{\mathrm{p}}\right) /\left(1+\exp \left(\mathrm{x}^{\mathrm{p}}+\mathrm{y}^{\mathrm{p}}\right)\right)
\end{aligned}
$$

$\operatorname{Pr}($ no collaboration $\mid$ patent $)=1 /\left(1+\exp \left(\mathrm{x}^{\mathrm{p}}+\mathrm{y}^{\mathrm{p}}\right)\right)$

$\operatorname{Pr}($ patent $\mid$ collaboration $)=\exp \left(\mathrm{V}^{\mathrm{p}}+\mathrm{x}^{\mathrm{p}}+\mathrm{y}^{\mathrm{p}}-\mathrm{V}-\mathrm{x}-\mathrm{y}\right) /$

$$
\begin{aligned}
& \left(1+\exp \left(\mathrm{V}^{\mathrm{p}}+\mathrm{x}^{\mathrm{p}}+\mathrm{y}^{\mathrm{p}}-\mathrm{V}-\mathrm{x}-\mathrm{y}\right)\right)=\exp \left(\mathrm{V}^{\prime}+\mathrm{x}^{\prime}+\mathrm{y}^{\prime}\right) / \\
& \left(1+\exp \left(\mathrm{V}^{\prime}+\mathrm{x}^{\prime}+\mathrm{y}^{\prime}\right)\right)
\end{aligned}
$$

$\operatorname{Pr}($ patent $\mid$ no collaboration $)=\exp \left(\mathrm{V}^{\prime}\right) /\left(1+\exp \left(\mathrm{V}^{\prime}\right)\right)$

\footnotetext{
${ }^{6}$ For instance, the payoff with no collaboration and no patenting is $V+\varepsilon_{1}$, where $\varepsilon$ is distributed with GEV type I distribution, and the other payoffs are analogously defined. These are the assumptions underlying the familiar multinomial logit model. Though we do show the joint probabilities using simple contingency tables, separately for leaders and followers, we do not estimate a multinomial logit because it would imply estimating a separate set of parameters for each of the choices. With limited number of observations, we chose to directly estimate the expectation of patenting conditional upon openness for leaders and followers.
} 
Some of the literature (e.g. Laursen and Salter, 2014) has effectively compared (5) with $\left(5^{\prime}\right) .^{7}$ Zobel et al. (2013) by contrast find that the conditional mean of patenting is higher for open than closed firms. They thus compare (6) and $\left(6^{\prime}\right)$.

Our framework allows us to infer something about the underlying benefits and costs of patenting and collaboration by observing the patenting and collaboration choices made by the firm. For instance, if one finds that patenting firms collaborate more than non-patenting firms, this lets us infer that the sum $x^{p}+y^{p}>0$. However, one might find that $\mathrm{x}^{\mathrm{p}}+\mathrm{y}^{\mathrm{p}}>0$ and $\mathrm{x}^{\mathrm{p}}+\mathrm{y}^{\mathrm{p}}<\mathrm{x}+\mathrm{y}$ can be both true, so that patenting actually reduces the benefit of collaboration compared to non-patenting. Again drawing on our framework above, we can see that $\mathrm{E}$ (Patenting| open) - E(Patenting| closed) is positive if and only if $\mathrm{x}^{\prime}+\mathrm{y}^{\prime}$ is positive. Therefore, a positive association between patenting and openness lets us infer that spillover-prevention dominates organizational-openness.

Thus far, however, we have treated all firms as homogeneous. If firms differ, as we argue they do, the average relationship may conceal significant differences, which are both of practical and theoretical significance. To see this we develop the framework further and use the subscripts $\mathrm{L}$ and $\mathrm{F}$ to denote leaders and followers respectively. As noted right at the beginning of this section we expect spillover prevention will dominate organizational openness for leaders because leaders have more to fear from imitation and knowledge spillovers. This is equivalent to $x_{L}^{\prime}+y_{L}^{\prime}>0$. In this situation we expect to find leaders patenting more than followers. Thus, If we observe $E$ (Patent $\mid$ open $)_{L}>E$ (Patent |closed $)_{L}$ then we can infer that spillover prevention dominates organizational openness for leaders, or, $x_{L}^{\prime}+y_{L}^{\prime}>0$ (Proposition 1a). ${ }^{8}$

Similarly, if $\mathrm{x}_{\mathrm{F}}^{\prime}+\mathrm{y}_{\mathrm{F}}^{\prime}<0$, then we could expect that organizational openness dominates spillover prevention for followers. Followers have less proprietary technical information. As followers, they also typically have less to fear that their spillovers will facilitate the entry of other competitors. Thus, firms that are open and seek to benefit from collaboration would also patent less. Thus, if we observe that $E$ (Patent $\mid$ open $)_{F}<E(\text { Patent } \mid \text { closed })_{F}$, we can infer that organizational openness dominates spillover prevention for followers, i.e., $x_{F}^{\prime}+y_{F}^{\prime}<0$ (Proposition $1 b$ ).

Comparing patenting by closed leaders and followers reveals the relative value of patenting for leaders and followers If $E$ (Patent $\mid$ closed $)_{L}>E(\text { Patent } \mid \text { closed })_{F}$ we can infer that leaders value patents more than followers even absent collaboration, i.e., $V_{L}^{\prime}>V_{F}^{\prime}$ (Proposition 2a).

Comparing patenting by open leaders and followers will reveal if open leaders gain more from patenting than open followers. That is,

If $E$ (Patent $\mid$ open $)_{L}>E(\text { Patent |open })_{F}$ then we infer that leaders value patents more when collaborating compared to followers, i.e., $\left(V_{L}^{\prime}+x_{L}^{\prime}+y_{L}^{\prime}\right)-\left(V_{F^{\prime}}^{\prime}+x_{F}^{\prime}+y_{F}^{\prime}\right)>0$ (Proposition $2 \mathrm{~b}$ ).

In our empirical analysis, we also test the more compact hypothesis $E(\text { Patent } \mid \text { open })_{L}-E(\text { Patent } \mid \text { closed })_{L}>E($ Patent $\mid$ open $)_{F}-E(\text { Patent } \mid \text { closed })_{F}$. This hypothesis, we believe, is the closest to intuitive argument that leaders are more susceptible to spillovers during collaboration than are followers. E(Patent | open $)_{L}-E$ (Patent $\mid$ closed $)_{L}$ represents the increase in patenting by leaders when they are open compared to when they are closed. $E(\text { Patent } \mid \text { open })_{F}-E(\text { Patent } \mid \text { closed })_{F}$ represents the corresponding change for followers. Put differently, the difference in patenting between open and closed firms will be larger among the group of firms classified as leaders when compared to the difference in

\footnotetext{
7 We treat collaboration (or openness) as well as patent as binary. For binary variables, the conditional mean is the same as the conditional probability, so that, for instance, $\operatorname{Pr}($ Collaboration $\mid$ patent $)=\mathrm{E}$ (collaborate $\mid$ patent $)$.

8 Proofs of this and other statements are provided in the appendix.
}

patenting between open and closed firms among followers. In statistical language we look for "differences in differences".

\section{Data, methods and variables}

\subsection{Data}

We use the Survey of Innovation and Patent Use (SIPU) commissioned by the UK Intellectual Property Office in September 2012 and administered by the telephone survey team of the Office of National Statistics to test our conjectures. The survey is based on a sampling frame drawn from the sixth wave of Community Innovation Survey (CIS 6) conducted in 2006-2008 and asked questions about firms' innovation and technology in-licensing activities over 2009-2012. The advantage of this sampling frame is that it gave us information on the antecedent technological behaviour of the surveyed firms.

The sample eligible for SIPU comprised of firms that agreed to be contacted again when they took part in the 2009 UK CIS (the CIS 6). In all 1365 firms were contacted and the survey achieved 801 completed interviews and 10 partial interviews, yielding a response rate of $60.1 \%$. 464 firms could not be contacted and 74 refused to participate in the survey. The SIPU sample yielded information on 329 innovating firms.

\subsection{Identifying open and closed firms}

We classify the 329 innovative firms into open and closed innovative firms. The openness is defined according to the number of different types of the firms' external collaborators. ${ }^{9}$ In the CIS 6 , firms are asked whether they cooperated in innovative activities with six types of organizations: suppliers of equipment, materials, services or software; clients or customers; competitors or other businesses in their industry; consultants, commercial labs, or private R\&D institutes; universities or other higher education institutions; and government or public institutes. If a firm collaborated with two or more types of external partners on innovation (the median number of collaborators is two), it is classified as an open innovative firm. Otherwise, it is considered as a closed innovative firm. This method resulted in approximately equal numbers of open and closed firms- there were 163 open and 166 closed firms.

\subsection{Identifying technology leaders and followers}

We use a $k$-means cluster analysis to classify firms as technology leaders or technology followers. ${ }^{10}$ The clustering was based on two variables, viz. R\&D intensity (measured the logarithm of internal $R \& D$ expenditure divided by number of employees) and the value of innovations (measured by the percentage of revenue

\footnotetext{
${ }^{9}$ Of these 329 firms, 81 firms had not reported an innovation in CIS 6 but 18 of those 81 had reported ongoing innovation and so were asked questions about collaboration. Only 1 firm of the 18 that had answered the question on collaboration had reported collaborating with a large number of partners. Furthermore, 47 of the remaining 63 firms (75\%) had neither bought external R\&D nor acquired a patent license (another measure of openness). Hence we treated all the 63 firms as being closed. Excluding these 63 firms from the sample altogether yields qualitatively similar results. We also get similar results if we reclassify firms as open or closed based on whether they had engaged in external technology acquisition, i.e. they either purchased technology licenses or externally contracted R\&D in our survey, or acquired external R\&D and acquired external knowledge in CIS6. The threshold of a firm being classified as open is lower and we found 193 open firms and correspondingly fewer closed firms.

10 The cluster procedure begins with two initial group centers. Observations are assigned to the group with the closest center. The mean of the observations assigned to each of the groups is computed, and the process is repeated. These steps continue until all observations remain in the same group from the previous iteration (Stata, 2015).
} 
Table 1

Summary Statistics of Leader and Follower Firms.

\begin{tabular}{llll}
\hline & R\&D intensity & $\begin{array}{l}\text { \% of revenue from } \\
\text { product innovation }\end{array}$ \\
\hline Leader & Minimum & 0 & 18 \\
& Mean & 1.03 & 32.39 \\
& Maximum & 4.17 & 75 \\
Follower & Minimum & 0 & 0 \\
& Mean & 0.38 & 3.03 \\
\multirow{2}{*}{ Total } & Maximum & 4.41 & 8 \\
& Minimum & 0 & 0 \\
& Mean & 0.64 & 14.62 \\
& Maximum & 4.41 & 75 \\
\hline
\end{tabular}

Table 2

Number of Firms in Four Categories by Leadership and Openness.

\begin{tabular}{llll}
\hline & Leader & Follower & Total \\
\hline Open & 70 & 93 & 163 \\
Closed & 61 & 105 & 166 \\
Total & 131 & 198 & 329 \\
\hline
\end{tabular}

from product innovation). Unlike openness, where we have roughly equal numbers of open and closed firms, the cluster analysis sensibly yields more followers than leaders. We report the average R\&D intensity and average turnover from innovations for firms classified as leaders and followers in Table 1. Based on the leadership and openness measures, we group the firms into four categories: open leader, closed leader, open follower and closed follower (Table 2).

\subsection{Patenting}

We follow Arora et al. (2014) by measuring whether the firm had applied for a patent for their most significant innovation. Respondents were asked, "Of all the new or significantly improved goods or services or processes you brought to market since November 2009, think of the one that accounts for the most turnover"- thus, the most significant innovation is their most valuable one. Then they were asked if they applied for a patent for this innovation. Around $1 / 6$ th of the innovative firms had patented their most significant innovation (see the mean of "whether the company applied for a patent for significant innovation", Table 3). ${ }^{11}$

We verified the robustness of our results using a second measure of patent propensity viz. the share of innovations patented. We follow Arundel and Kabla (1998) and Cohen et al. (2000) in the SIPU survey to ask firms what percentage of their innovations was associated with patent applications. In response, firms were asked to select one of six bands for the innovations viz. less than $10 \%$, $10-40 \%, 41-60 \%, 61-90 \%$, over $90 \%$. We assume that the percentage in each band is concentrated around the midpoint. Among all respondents, the mean share of innovations patented is around $5 \%$. For patenting firms only, the mean share of innovations patented is about $26 \%$. Both measures yield very similar results. We only feature the results for whether the firm had patented its most significant innovation because typically firms have only a few innovations. The featured measure minimizes measurement error. ${ }^{12}$ As well, we can control for whether the innovation is a product inno-

\footnotetext{
11 Most of the extant literature uses a dummy variable indicating whether the firm has patented or not as an indicator of patent use. This measure of patent use does not allow us to control for the scale of innovations-larger firms will have more innovations and so will more often patent more. Moreover, firms with multiple innovations are more likely to file at least one patent than a firm, with the same patent propensity, which has few innovations because of a smaller scale.

12 We are grateful to an anonymous referee for highlighting this point.
}

vation or not. Doing so is important because process innovations are typically less likely to be patented.

\subsection{Control variables}

To control for the influence of the codifiability of firms' knowledge on the patentability of their innovations, we follow Brusoni et al. (2005) and create a variable codification of knowledge based on the perceived importance of information from scientific journals and trade/technical publications and importance of information from technical, industry or service standards to firms' innovation related activities, which are recorded in the CIS 6. The CIS6 asks firms to rank from 0 to 3 the importance of information received from various sources to a firm's innovation activities, where 0 indicates that the source is not used and 3 indicates that it is very important. The value of codification of knowledge is the highest value that a firm gave to these two sources.

We use the logarithmic employment as a measurement of a firm's size. In the regression with the dependent variable of whether the company applied for a patent for significant innovation, we add a control variable turnover from significant innovation to control for the importance of the significant innovation to the firm. In the SIPU, firms were asked to indicate what percentage of total turnover was from the significant innovation, such as $1-5 \%, 6-10 \%, 11-25 \%$, $26-50 \%$ and more than $50 \%$. We take the midpoint in each band as the value for the control variable. We also add a dummy variable significant innovation is a new good to control for the higher probability that a new good would be patented in comparison to the probability that a new service or process would be patented.

To control for industry characteristics, we generated 17 dummy variables at the two-digit industry level. A dummy variable is assigned to a two-digit industry as long as there are greater than 8 observations from this industry. Our results are unchanged if we use other industry controls, such as classifying industries into high, medium, and low technology intensity groups. The summary statistics and correlation matrix of the variables are presented in Table 3.

\section{Empirical analysis}

We begin by showing the joint distribution between openness and patenting, specifically the four probabilities given by expressions (1)-(4). The data indicate a modest positive relationship between openness and patenting. This positive relationship is much stronger for leaders, but reversed for followers. We follow up on this analysis with a more traditional regression analysis where we estimate the expected value of patenting conditional upon whether the firm is a leader or not, and whether it is open or not, controlling for various firm characteristics. We prefer this approach to the more obvious multinomial logit because it links our paper more closely to the existing literature, and makes it easy to see how the increase in patenting between open and closed firms varies between leaders and followers. A multinomial logit also requires estimating three times as many parameters, greatly reducing the statistical power of tests of differences. ${ }^{13}$

\subsection{Descriptive analysis}

We begin with a simple descriptive analysis where we divide firms into whether they patent their most significant innovation (henceforth, patent) and whether they are open. Table 4a shows the result for the sample as a whole. The numbers in each cell

\footnotetext{
13 The multinomial logit estimates yield qualitatively similar results.
} 
Table 3

Summary statistics and correlation matrix.

\begin{tabular}{|c|c|c|c|c|c|c|c|c|c|c|c|c|c|c|c|}
\hline & \multirow[t]{2}{*}{ Variables } & \multirow{2}{*}{$\begin{array}{l}\text { Number of } \\
\text { Observations }\end{array}$} & \multirow[t]{2}{*}{ Mean } & \multirow{2}{*}{$\begin{array}{l}\text { Standard } \\
\text { Deviation }\end{array}$} & \multirow[t]{2}{*}{ Min } & \multirow[t]{2}{*}{ Max } & \multirow[b]{2}{*}{1} & \multirow[b]{2}{*}{2} & \multirow[b]{2}{*}{3} & \multirow[b]{2}{*}{4} & \multirow[b]{2}{*}{5} & \multirow[b]{2}{*}{6} & \multirow[b]{2}{*}{7} & \multirow[b]{2}{*}{8} & \multirow[b]{2}{*}{9} \\
\hline & & & & & & & & & & & & & & & \\
\hline 1 & $\begin{array}{l}\text { Innovator applied for a } \\
\text { patent for significant } \\
\text { innovation }\end{array}$ & 328 & 15.85 & 36.58 & 0.00 & 100.00 & 1.00 & & & & & & & & \\
\hline 2 & Open leader & 329 & 0.21 & 0.41 & 0.00 & 1.00 & 0.15 & 1.00 & & & & & & & \\
\hline 3 & Closed leader & 329 & 0.19 & 0.39 & 0.00 & 1.00 & -0.05 & -0.25 & 1.00 & & & & & & \\
\hline 4 & Open follower & 329 & 0.28 & 0.45 & 0.00 & 1.00 & -0.05 & -0.33 & -0.31 & 1.00 & & & & & \\
\hline 5 & Closed follower & 329 & 0.32 & 0.47 & 0.00 & 1.00 & -0.05 & -0.35 & -0.32 & -0.42 & 1.00 & & & & \\
\hline 6 & Log employment & 329 & 4.01 & 1.40 & 1.39 & 9.83 & 0.12 & -0.04 & -0.01 & 0.10 & -0.06 & 1.00 & & & \\
\hline 7 & Codified knowledge & 329 & 1.31 & 1.07 & 0.00 & 3.00 & 0.10 & 0.22 & -0.11 & 0.25 & -0.35 & 0.09 & 1.00 & & \\
\hline 8 & Turnover from significant innovation & 316 & 0.14 & 0.20 & 0.00 & 0.75 & -0.01 & 0.29 & 0.07 & -0.17 & -0.15 & -0.07 & 0.04 & 1.00 & \\
\hline 9 & Significant innovation is a new good & 329 & 0.60 & 0.49 & 0.00 & 1.00 & 0.22 & 0.26 & 0.00 & -0.09 & -0.14 & -0.03 & 0.06 & -0.07 & 1.00 \\
\hline
\end{tabular}

Table 4a

Openness and patenting of focal innovation: all firms.

\begin{tabular}{llll}
\hline & Patent & Not Patent & Total \\
\hline Open & 30 & 133 & 163 \\
& $9.15 \%$ & $40.55 \%$ & $49.7 \%$ \\
Closed & 22 & 143 & 165 \\
& $6.71 \%$ & $43.6 \%$ & $50.3 \%$ \\
Total & 52 & 276 & 328 \\
& $15.85 \%$ & $84.15 \%$ & $100 \%$ \\
\hline
\end{tabular}

Table 4b

Openness and patenting of focal innovation: leaders.

\begin{tabular}{llll}
\hline & Patent & Not Patent & Total \\
\hline Open & 18 & 52 & 70 \\
& $13.85 \%$ & $40 \%$ & $53.85 \%$ \\
Closed & 7 & 53 & 60 \\
& $5.38 \%$ & $40.77 \%$ & $46.15 \%$ \\
Total & 25 & 105 & 130 \\
& $19.23 \%$ & $80.77 \%$ & $100 \%$ \\
\hline
\end{tabular}

Table 4c

Openness and patenting of focal innovation: followers.

\begin{tabular}{llll}
\hline & Patent & Not Patent & Total \\
\hline Open & 12 & 81 & 93 \\
& $6.06 \%$ & $40.91 \%$ & $46.97 \%$ \\
Closed & 15 & 90 & 105 \\
& $7.58 \%$ & $45.45 \%$ & $53.03 \%$ \\
Total & 27 & 171 & 198 \\
& $13.64 \%$ & $86.36 \%$ & $100 \%$ \\
\hline
\end{tabular}

are the counts of the firms in each category, and their share in the total sample. These correspond to the joint probabilities of openness and patenting. Note that there is a modest positive association between openness and patenting. For instance, overall about $16 \%$ of innovators patent, whereas over $22.5 \%$ of open innovators patent.

To relate this to the model developed in Section 3 , we note that $[\operatorname{Pr}($ open \& patent $)-\operatorname{Pr}($ open \& no patent $)]-[\operatorname{Pr}($ closed \& patent $)-\operatorname{Pr}($ closed \& no patent $)]=[9.15 \%-$ $40.55 \%]-[6.71 \%-43.60 \%]=5.49 \%$ consistent with the notion that overall patenting and openness are positively associated.

Tables 4b and 4c show the same results separately for technology leaders and followers respectively. In Table $4 \mathrm{~b}$ we see clearly that the positive association between patenting and collaboration is much stronger than average in the case of technology leaders. Table 4c shows virtually no relationship between patenting and openness for followers. In other words, these simple descriptive findings suggest that for leaders, spillover prevention dominates
Table 4d

Percentage of firms patenting focal innovation.

\begin{tabular}{llll}
\hline & Leader & Follower & Leader minus follower \\
\hline Open & 25.71 & 12.90 & $12.81^{* *}$ \\
& $(5.26)$ & $(3.50)$ & $(6.09)$ \\
Closed & 11.67 & 14.29 & -2.62 \\
& $(4.18)$ & $(3.43)$ & $(5.53)$ \\
Open minus Closed & $14.05^{* *}$ & -1.38 & \\
& $(6.88)$ & $(4.91)$ & \\
\hline
\end{tabular}

Note: The numbers in parentheses are standard errors. ${ }^{* * *}$ denotes a significance level of $1 \%,{ }^{* *}$ denotes a significance level of $5 \%,{ }^{*}$ denotes a significance level of $10 \%$.

organizational openness, whereas the two forces appear to largely balance each other for followers.

Table 4d summarizes this point by showing the conditional probabilities, which much of the literature has implicitly focused on. The difference in patenting between open and closed firms varies between leaders and followers. We see that $\mathrm{E}$ (patent lopen leader) is nearly $26 \%$ while $\mathrm{E}$ (patent |closed leader) is less than $12 \%$; Open leaders are twice as likely to patent as close leaders. Instead, $\mathrm{E}$ (patent | open follower) is $13 \%$ whereas $\mathrm{E}$ (patent | closed follower) is $14 \%$; open followers are slightly less likely to patent than close followers, although the difference is not statistically significant.

These patterns are consistent with our theoretical argument that leaders are more vulnerable to spillovers. Thus, when leaders collaborate in innovation they are more likely to use patents than when they innovate internally, and this difference is large and statistically significant. However, when followers collaborate in innovation, they are not more likely to patent than when they innovate internally.

\subsection{Regression analysis}

The simple differences in conditional means do not control for a variety of other factors, such as scale and industry characteristics. Accordingly, we estimate the expectation of whether the firm patents its most significant innovation conditional on the firm type (e.g., open leader, closed leader, open follower, closed follower), as well as a variety of firm characteristics and industry dummies. The most straightforward way of doing so is through a linear regression specification; the estimated regression coefficients are the conditional means we theorize about. Probits or logits yield very similar results.

Since we are using the coefficients of the regression equation on the four groups (open leader, closed leader, open follower and closed follower) as a measure of conditional mean of patenting, the statistical significance of the coefficient is less important for our analysis than the difference in coefficient values across the groups. Thus, we report in Table $5 \mathrm{~b}$ the results on a number of F-tests which 
Table 5a

OLS regression. Dependent variable = 1 if Innovator applied for a patent for significant innovation.

\begin{tabular}{|c|c|c|c|c|c|}
\hline & (1) & $(2)$ & (3) & (4) & (5) \\
\hline Open leader & $\begin{array}{l}25.71 \\
(5.26)\end{array}$ & $\begin{array}{l}22.01 \\
(8.10)\end{array}$ & $\begin{array}{l}13.54 \\
(9.94)\end{array}$ & $\begin{array}{l}12.64 \\
(10.70)\end{array}$ & $\begin{array}{l}2.66 \\
(11.29)\end{array}$ \\
\hline Closed leader & $\begin{array}{l}11.67 \\
(4.17)\end{array}$ & $\begin{array}{l}10.75 \\
(6.98)\end{array}$ & $\begin{array}{l}2.19 \\
(9.52)\end{array}$ & $\begin{array}{l}2.05 \\
(9.99)\end{array}$ & $\begin{array}{l}-5.73 \\
(9.97)\end{array}$ \\
\hline Open follower & $\begin{array}{l}12.90 \\
(3.50)\end{array}$ & $\begin{array}{l}10.08 \\
(7.04)\end{array}$ & $\begin{array}{l}1.41 \\
(8.88)\end{array}$ & $\begin{array}{l}-0.80 \\
(9.75)\end{array}$ & $\begin{array}{l}-7.26 \\
(10.15)\end{array}$ \\
\hline Closed follower & 14.29 & $\begin{array}{l}14.78 \\
(6.59)\end{array}$ & $\begin{array}{l}6.69 \\
(9.01)\end{array}$ & $\begin{array}{l}6.14 \\
(9.69)\end{array}$ & $\begin{array}{l}-0.26 \\
(9.69)\end{array}$ \\
\hline Log employment & & & $\begin{array}{l}2.20 \\
(1.67)\end{array}$ & $\begin{array}{l}2.29 \\
(1.73)\end{array}$ & $\begin{array}{l}2.54 \\
(1.70)\end{array}$ \\
\hline Codification of knowledge & & & & $\begin{array}{l}2.00 \\
(2.27)\end{array}$ & $\begin{array}{l}2.10 \\
(2.23)\end{array}$ \\
\hline Turnover from significant innovation & & & & $\begin{array}{l}-3.85 \\
(10.92)\end{array}$ & $\begin{array}{l}-0.28 \\
(10.82)\end{array}$ \\
\hline Significant innovation is a new good & & & & & $\begin{array}{l}10.33 \\
(4.14)\end{array}$ \\
\hline 17 industry dummies & No & Yes & Yes & Yes & Yes \\
\hline $\mathrm{N}$ & 328 & 328 & 328 & 316 & 316 \\
\hline $\mathrm{R}^{2}$ & 0.18 & 0.26 & 0.26 & 0.27 & 0.28 \\
\hline F-statistic & $15.66^{* * *}$ & $3.28^{* * *}$ & $3.19^{* * *}$ & $2.90^{* * *}$ & $2.85^{* * *}$ \\
\hline
\end{tabular}

Table 5b

Size and F-Statistics for difference in estimated coefficients.

\begin{tabular}{|c|c|c|c|c|c|c|}
\hline & & \multicolumn{5}{|c|}{ F Statistics for difference in estimated coefficients in the OLS model } \\
\hline & & $(1)$ & $(2)$ & (3) & $(4)$ & $(5)$ \\
\hline \multirow[t]{2}{*}{ H0: coefficient of open leader = coefficient of closed leader } & Difference & 14.05 & 11.26 & 11.35 & 10.59 & 8.39 \\
\hline & F-value & $4.38^{* *}$ & $2.89^{*}$ & $2.95^{*}$ & 2.27 & 1.37 \\
\hline \multirow[t]{2}{*}{ H0: coefficient of open leader = coefficient of open follower } & Difference & 12.81 & 11.93 & 12.13 & 13.44 & 9.92 \\
\hline & F-value & $4.12^{* *}$ & $3.55^{*}$ & $3.74^{* *}$ & $4.12^{* *}$ & 2.16 \\
\hline \multirow[t]{2}{*}{ H0: coefficient of closed leader = coefficient of closed follower } & Difference & -2.62 & -4.03 & -4.5 & -4.09 & -5.47 \\
\hline & F-value & 0.23 & 0.55 & 0.67 & 0.54 & 1.02 \\
\hline \multirow[t]{2}{*}{ H0: coefficient of open follower = coefficient of closed follower } & Difference & -1.39 & -4.7 & -5.28 & -6.94 & -7.0 \\
\hline & F-value & 0.08 & 0.91 & 1.20 & 1.66 & 1.75 \\
\hline \multirow{2}{*}{$\begin{array}{l}\text { H0: coefficient of open leader - coefficient of closed leader = coefficient } \\
\text { of open follower - coefficient of closed follower }\end{array}$} & Difference & 15.43 & 16.63 & 16.63 & 17.53 & 15.39 \\
\hline & F-value & $3.45^{*}$ & $3.95^{* *}$ & $4.34^{* *}$ & $4.52^{* *}$ & $3.47^{*}$ \\
\hline
\end{tabular}

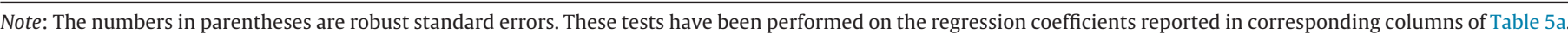
*** denotes a significance level of $1 \%,{ }^{* *}$ denotes a significance level of $5 \%,{ }^{*}$ denotes a significance level of 10 .

tests the equivalence of the conditional mean for patenting. Each column of Table $5 \mathrm{~b}$ corresponds to a column of reported coefficients in Table 5a. We also examine whether the difference in patenting between open and closed leaders is greater than the corresponding difference in patenting among followers. Formally, we test that the "difference in difference" is positive and significant and the twotailed test of this hypothesis is reported in the last row of Table 5b.

Tables $5 \mathrm{a}$ and $5 \mathrm{~b}$ show that the patterns shown in Tables $4 \mathrm{a}-4 \mathrm{c}$ hold even after controlling for firm and technology characteristics, and industry fixed effects. In the first column of Table 5a, we regress the four choices of firms against the use of patents to protect their most significant innovation and do not include any industry dummies or firm controls. Column 1 in Table $5 b$ thus reproduces the specification implied by Table $4 \mathrm{~d}$. We see that $\mathrm{E}(\text { patent } \mid \text { open })_{\mathrm{L}}-\mathrm{E}(\text { patent } \mid \text { closed })_{\mathrm{L}}=25.71-11.67=14.05$, which is both large and statistically significant, as shown in the first row of Table 5b. Following our discussion in Section 3, we infer that $x_{L}^{\prime}+y_{L}^{\prime}>0$ (Proposition 1a).

Similarly, we find that $\mathrm{E}$ (patent lopen)L-E(patent lopen) $\mathrm{F}=12.8$, also large and statistically significant. Inclusion of additional controls does not change this result very much (see second row of Table 5b). Following the discussion in Section 3 (Proposition 2b), we infer that $\left.\left(V_{L}^{\prime}+x_{L}^{\prime}+y_{L}^{\prime}\right)-V_{F}^{\prime}+x_{F}^{\prime}+y_{F}^{\prime}\right)>0$. However, we also find that $\mathrm{E}$ (patent $\mid$ closed) $)_{\mathrm{L}}-\mathrm{E}$ (patent $\mid$ closed $)_{\mathrm{F}}$ is -2.62 , but statistically insignificant. As formally demonstrated in Proposition 2a, this implies that $\mathrm{V}_{\mathrm{L}^{\prime}}=\mathrm{V}_{\mathrm{F}^{\prime}}$. As well, $\mathrm{E}$ (patent lopen $)_{F}-E$ (patent $\mid$ closed $)_{F}$ is slightly negative, but statistically insignificant, at -1.38 . According to Proposition $1 \mathrm{~b}$, this implies $\mathrm{x}_{\mathrm{F}}^{\prime}+\mathrm{y}_{\mathrm{F}}^{\prime}=0$.

Consistent with these findings, the change in patenting for followers that collaborate compared to followers that do not collaborate is significantly smaller than for leaders.i.e., $\{\mathrm{E}$ (patent I open $)_{\mathrm{L}}-\mathrm{E}$ (patent $\mid$ closed $\left.)_{\mathrm{L}}\right\}-\{\mathrm{E} \text { (patent } \text { |open })_{\mathrm{F}}-\mathrm{E}$ (patent $\mid$ closed $\left.)_{\mathrm{F}}\right\}=15 \%$, which is both large (recall that mean patenting rate is only slightly larger than 15\%) and statistically significant, as can be seen in the last row of Table 5b.

Column 2 shows that including 17 industry fixed effects has only a slight effect on the differences in the conditional means. The difference in patenting rates between open and closed leaders decreases from about $14 \%$ to about $11 \%$ once industry effects are included. However, the difference in patenting rates between open and closed followers becomes more negative (increases in 
absolute value), from $-1.4 \%$ to about $-4.7 \%$. As a result, the "difference in difference" also increases slightly from $15.4 \%$ to $16.0 \%$. This difference in difference is statistically significant and quantitatively large, equal to the mean rate of patenting in the sample as a whole.

Columns 3 and 4 progressively add controls for firm size, codification of knowledge and percentage of turnover from significant innovation. Although the differences in conditional means remain more stable, the precision of the estimates falls as standard errors increase. For instance, in Column 3, the differences in patenting rates between open and closed leaders is about $11.4 \%$, whereas the difference between open and closed followers is nearly $-5.3 \%$. The difference in difference actually increases to $16.6 \%$ (compared to $16.0 \%$ with only industry effects). Column 5 additionally controls for whether the significant innovation is a good (henceforth, a product innovation), rather than a service or process. Product innovations are more likely to be patented (Cohen et al., 2000). Compared to processes, products are harder to protect through secrecy but infringement of product patents is easier to detect and litigate. Further, recall from Table 3 that leaders are more likely to introduce product innovations. Indeed, we find that product innovations are more likely to be patented, and controlling for the nature of the innovation, significantly reduces the size of the estimated coefficients for both open and closed leaders. However, the difference in patenting rates between open and closed leaders decreases only slightly to $8.4 \%$. The difference between open and closed followers is $-7.0 \%$, so that the difference-in-difference is $15.4 \%$, which is similar in magnitude to the other specifications and statistically significant as well.

In sum, we find that open leaders patent more than closed leaders, and that open leaders patent more than open followers. However, closed leaders patent at similar rates as closed followers and open followers. It follows that the association between openness and patenting is positive and significant for leaders, and is significantly larger than the association between openness and patenting for followers. From this, using our framework we infer that for UK CIS6 firms $x_{L}^{\prime}+y_{L}^{\prime}$ is positive and $x_{F}^{\prime}+y_{F}^{\prime}=0$. These relationships imply that leaders are vulnerable to spillovers while collaborating and this concern outweighs any potential benefits from attracting collaborators and enhancing the efficiency of collaboration. By contrast, for followers any concerns about spillovers of background knowledge appear to be balanced by benefits from openness in terms of enhancing the efficiency of collaboration. Interestingly, we also find that $V_{L}^{\prime}=V_{F}^{\prime}$ which suggests that both leaders and followers have similar valuations for the traditional benefits of patents.

\section{Conclusion}

This paper has revisited the "paradox of openness", which describes a trade-off when firms open up to outsiders to generate knowledge may weaken the firm's power to capture knowledge. Associated with this paradox, there are two opposing theoretical hypotheses. On the one hand, firms are more likely to seek external collaborators if they can protect their innovation by patents, and more generally, can guard against unintended knowledge spillovers to partners. We call it the "spillover prevention" theory. In this view, we expect to see a positive correlation between patenting and openness. On the other hand, patenting and exclusivity makes a firm less efficient in developing collaborative innovations, and hence also, a less attractive partner. We dub this the "organizational openness" theory. It implies a negative relationship between patenting and openness.

In this paper we start from the premise that both patenting and openness are jointly determined, and therefore, one cannot use a causal inference approach, common in this literature. We therefore develop a simple empirical framework that incorporates the joint determination of both variables. We argue that the relationship between patenting and openness is contingent on the technological and innovation leadership of firms. Firms will make different choices about being open and about patenting depending upon whether they are technically superior to their rivals. We use our framework to derive the empirical implications of this contingency for the relationship between patenting and openness. We test this empirically, using a novel survey of a sample of over 325 innovative firms that were also covered in the sixth wave of the UK Community Innovation Survey.

We conclude that the trade-off between openness and patenting is resolved differently by different types of firms. Leading firms are more vulnerable to unintended knowledge spillovers during collaboration as compared to followers, and consequently, we find that the increase in patenting due to openness is higher for leaders than for followers. Followers, with incremental innovations that benefit less from patenting and with little proprietary technology and knowhow, may be less willing to patent because it makes them a less attractive open partner and perhaps also less able to derive value from collaboration.

Our model was simple as it enabled us to work with the firm level data we have. However, it is plausible that firms may lead in some areas but follow in others. Indeed collaboration works because firms have strengths in complementary technologies and pooling resources can help both firms to gain from the others' expertise. Is the relationship between openness and patenting best analysed at the project level rather than the firm level? And if so, how do the choices in one project affect those in future projects? Answering these questions requires refining the simple theoretical model developed here. It also requires as well as more disaggregated innovation project-level data, which we currently lack. We hope however that our paper stimulates additional research on this and other dimensions of the tradeoff between appropriability and openness. ${ }^{14}$

\section{Appendix A.}

The following relationships are useful, and have been derived in the text.

$\operatorname{Pr}(\text { Patent|open })_{\mathrm{L}}=\exp \left(\mathrm{V}_{\mathrm{L}}^{\prime}+\mathrm{x}_{\mathrm{L}}^{\prime}+\mathrm{y}_{\mathrm{L}}^{\prime}\right) /\left(1+\exp \left(\mathrm{V}_{\mathrm{L}}^{\prime}+\mathrm{x}_{\mathrm{L}}^{\prime}+\mathrm{y}_{\mathrm{L}}^{\prime}\right)\right)$
$\operatorname{Pr}(\text { Patent|closed })_{\mathrm{L}}=\exp \left(\mathrm{V}_{\mathrm{L}}^{\prime}\right) /\left(1+\exp \left(\mathrm{V}_{\mathrm{L}}^{\prime}\right)\right)$
$\operatorname{Pr}(\text { Patent|open })_{\mathrm{F}}=\exp \left(\mathrm{V}_{\mathrm{F}}^{\prime}+\mathrm{x}_{\mathrm{F}}^{\prime}+\mathrm{y}_{\mathrm{F}}^{\prime}\right) /\left(1+\exp \left(\mathrm{V}_{\mathrm{F}}^{\prime}+\mathrm{x}_{\mathrm{F}}^{\prime}+\mathrm{y}_{\mathrm{F}}^{\prime}\right)\right)$
$\operatorname{Pr}(\text { Patent } \mid \text { closed })_{\mathrm{F}}=\exp \left(\mathrm{V}_{\mathrm{F}}^{\prime}\right) /\left(1+\exp \left(\mathrm{V}_{\mathrm{F}}^{\prime}\right)\right)$

Proposition 1a. E(Patent |open $)_{L}>E(\text { Patent } \mid \text { closed })_{L}$ iff $x_{L}^{\prime}+y_{L}^{\prime}>0$

Proposition 1b. E(Patent $\mid$ open $)_{F}<E(\text { Patent } \mid \text { closed })_{F}$ iff $x_{F}^{\prime}+y_{F}^{\prime}<0$

Proof of Proposition 1

$\mathrm{E}(\text { Patent } \mid \text { open })_{\mathrm{L}}-\mathrm{E}($ Patent $\mid$ closed $)=\operatorname{Pr}(\text { Patent } \mid \text { open })_{\mathrm{L}}$ $-\operatorname{Pr}(\text { Patent } \mid \text { closed })_{\mathrm{L}}$

$$
\begin{aligned}
= & \left\{\exp \left(\mathrm{V}_{\mathrm{L}}^{\prime}+\mathrm{x}_{\mathrm{L}}^{\prime}+\mathrm{y}_{\mathrm{L}}^{\prime}\right)-\exp \left(\mathrm{V}_{\mathrm{L}}^{\prime}\right)\right\} / \\
& \left\{1+\exp \left(\mathrm{V}_{\mathrm{F}}^{\prime}+\mathrm{x}_{\mathrm{F}}^{\prime}+\mathrm{y}_{\mathrm{F}}^{\prime}\right)\left(1+\exp \left(\mathrm{V}_{\mathrm{L}}^{\prime}\right)\right\}\right.
\end{aligned}
$$

\footnotetext{
${ }^{14}$ We are grateful to an anonymous reviewer for raising this point.
} 
$=\left\{\exp \left(\mathrm{V}_{\mathrm{L}}^{\prime}\right)\left(\exp \left(\mathrm{x}_{\mathrm{L}}^{\prime}+\mathrm{y}_{\mathrm{L}}^{\prime}\right)-1\right)\right\} /$

$$
\left\{\left(1+\exp \left(\mathrm{V}_{\mathrm{F}}^{\prime}+\mathrm{x}_{\mathrm{F}}^{\prime}+\mathrm{y}_{\mathrm{F}}^{\prime}\right)\left(1+\exp \left(\mathrm{V}_{\mathrm{L}}^{\prime}\right)\right\}\right.\right.
$$

$>0$ iff $\exp \left(\mathrm{x}_{\mathrm{L}}^{\prime}+\mathrm{y}_{\mathrm{L}}^{\prime}\right)>1$ iff $\mathrm{x}_{\mathrm{L}}^{\prime}+\mathrm{y}_{\mathrm{L}}^{\prime}>0$

The proof of $1 \mathrm{~b}$ follows similarly.

Proposition 2a. E(Patent $\mid$ closed $)_{L}>E(\text { Patent } \mid \text { closed })_{F}$ iff $V_{L}^{\prime}>V_{F}^{\prime}$, and

Proposition 2b. E(Patent | open $)_{L}>E(\text { Patent lopen })_{F}$ iff $V_{L}^{\prime}+x_{L}^{\prime}+y_{L}^{\prime}>V_{F}^{\prime}+x_{F}^{\prime}+y_{F}^{\prime}$

Proof of proposition 2

$\mathrm{E}(\text { Patent } \mid \text { closed })_{\mathrm{L}}-\mathrm{E}(\text { Patent } \mid \text { closed })_{\mathrm{F}}=\operatorname{Pr}(\text { Patent } \mid \text { closed })_{\mathrm{L}}$ $-\operatorname{Pr}(\text { Patent } \mid \text { closed })_{\mathrm{F}}$

$=\exp \left(\mathrm{V}_{\mathrm{L}}^{\prime}\right) /\left(1+\exp \left(\mathrm{V}_{\mathrm{L}}^{\prime}\right)\right)-\exp \left(\mathrm{V}_{\mathrm{F}}^{\prime}\right) /\left(1+\exp \left(\mathrm{V}_{\mathrm{F}}^{\prime}\right)\right)$

$=\left\{\exp \left(\mathrm{V}_{\mathrm{L}}^{\prime}\right)-\exp \left(\mathrm{V}_{\mathrm{F}}^{\prime}\right)\right\} /\left\{\left(1+\exp \left(\mathrm{V}_{\mathrm{L}}^{\prime}\right)\left(1+\exp \left(\mathrm{V}_{\mathrm{F}}^{\prime}\right)\right\}\right.\right.$

$>0$ iff $V^{\prime}{ }_{L}>V_{F}^{\prime}$

$\mathrm{E}(\text { Patent } \mid \text { open })_{\mathrm{L}}-\mathrm{E}(\text { Patent } \mid \text { open })_{\mathrm{F}}=\operatorname{Pr}(\text { Patent } \mid \text { open })_{\mathrm{L}}$ $-\operatorname{Pr}(\text { Patent|open })_{\mathrm{F}}$

$=\exp \left(\mathrm{V}_{\mathrm{L}}^{\prime}+\mathrm{x}_{\mathrm{L}}^{\prime}+\mathrm{y}_{\mathrm{L}}^{\prime}\right) /\left(1+\exp \left(\mathrm{V}_{\mathrm{L}}^{\prime}+\mathrm{x}_{\mathrm{L}}^{\prime}+\mathrm{y}_{\mathrm{L}}^{\prime}\right)\right)$

$-\exp \left(\mathrm{V}_{\mathrm{F}}^{\prime}+\mathrm{x}_{\mathrm{F}}^{\prime}+\mathrm{y}_{\mathrm{F}}^{\prime}\right) /\left(1+\exp \left(\mathrm{V}_{\mathrm{F}}^{\prime}{ } \mathrm{X}_{\mathrm{F}}^{\prime}+\mathrm{y}_{\mathrm{F}}^{\prime}{ }\right)\right)$

$=\left\{\exp \left(\mathrm{V}_{\mathrm{L}}^{\prime}+\mathrm{x}_{\mathrm{L}}^{\prime}+\mathrm{y}_{\mathrm{L}}^{\prime}\right)-\exp \left(\mathrm{V}_{\mathrm{F}}^{\prime}+\mathrm{x}_{\mathrm{F}}^{\prime}+\mathrm{y}_{\mathrm{F}}^{\prime}\right)\right\} /$

$\left\{\left(1+\exp \left(\mathrm{V}_{\mathrm{L}}^{\prime}+\mathrm{x}_{\mathrm{L}}^{\prime}+\mathrm{y}_{\mathrm{L}}^{\prime}\right)\right)\left(1+\exp \left(\mathrm{V}_{\mathrm{F}}^{\prime}+\mathrm{x}_{\mathrm{F}}^{\prime}+\mathrm{y}_{\mathrm{F}}^{\prime}\right)\right)\right\}$

$>0$ iff $V_{L}^{\prime}+x_{L}^{\prime}+y_{L}^{\prime}>V_{F}^{\prime}+x_{F}^{\prime}+y_{F}^{\prime}$

\section{Reference:}

Alcácer, J., Chung, W., 2014. Location strategies for agglomeration economies. Strateg. Manage. J. 35, 1749-1761.

Alexy, O., Criscuolo, P., Salter, A., 2009. Does IP strategy have to cripple open innovation? MIT Sloan Manage. Rev. 51, 71-77.

Alexy, O., George, G., Salter, A.I., 2013. Cui bono? the selective revealing of knowledge and its implication for innovative activity. Acad. Manage. Rev. 38, 270-291.

Alexy, O., Bascavusoglu-moreau, E., Salter, A., 2014. Toward a behavioral theory of open innovation. In: Paper to Be Presented at the DRUID Society Conference 2014, CBS, Copenhagen, June, pp. 16-18.

Allen, R.C., 1983. Collective invention. J. Econ. Behav. Organ. 4, 1-24.

Arora, A., Gambardella, A., 1994. The changing technology of technological change: general and abstract knowledge and the division of innovative labour. Res. Policy 23, 523-532.
Arora, A., Gambardella, A., 2010. The market for technology. In: Hall, B., Rosenberg, N. (Eds.), Handbook of the Economics of Innovation., pp. 641-678.

Arora, A., Merges, R.P., 2004. Specialized supply firms, property rights and firm boundaries. Ind. Corp. Change 13, 451-475.

Arora, A., Cohen, W., Walsh, J., 2014. The acquisition and commercialization of invention in American manufacturing: incidence and impact. Res. Policy 45 (6), 1113-1128.

Arora, Ashish, Fosfuri, Andrea, Gambardella, Alfonso, 2001. Markets for Technology: The Economics of Innovation and Corporate Strategy. MIT Press. Arrow, K., 1962. Economic welfare and the allocation of resources for invention. The rate and direction of inventive activity: economic and social factors. NBER, 609-626.

Arundel, A., Kabla, I., 1998. What percentage of innovations are patented? Empirical estimates for European firms. Res. Policy 27, 127-141.

Arundel, A., 2001. The relative effectiveness of patents and secrecy for appropriation. Res. Policy 30, 611-624.

Bessen, J., Nuvolari, A., 2012. Diffusing New Technology Without Dissipating Rents: Some historical case studies of knowledge sharing. (From SSRN.)

Brusoni, S., Marsili, O., Salter, A., 2005. The role of codified sources of knowledge in innovation: empirical evidence from Dutch manufacturing. J. Evol. Econ. 15, 211-231.

Buss, P., Peukert, C., 2015. R\&D outsourcing and intellectual property infringement. Res. Policy 44, 977-989.

Cassiman, B., Veugelers, R., 2002. R\&D cooperation and spillovers: some empirical evidence from Belgium. Am. Econ. Rev. 92, 1169-1184.

Chesbrough, H.W., Appleyard, M.M., 2007. Open innovation and strategy. Calif. Manage. Rev. 50, 57-76.

Chesbrough, H.W., 2003. Open Innovation: The New Imperative for Creating and Profiting from Technology. Harvard Business Press.

Chung, W., Alcacer, J., 2002. Knowledge seeking and location choice of foreign direct investment in the United States. Manage. Sci. 48, 1534-1554.

Cohen, W.M., Nelson, R.R., Walsh, J.P., 2000. Protecting their intellectual assets: appropriability conditions and why U.S. manufacturing firms patent (or not). In: NBER Working Paper 7552, Boston MA.

Foss, N., Laursen, K., Pedersen, T., 2011. Linking customer interaction and innovation: the mediating role of new organizational practices. Organ. Sci. 22 (July-August (4)), 980-999.

Gans, J.S., Hsu, D.H., Stern, S., 2008. The impact of uncertain intellectual property rights on the market for ideas: evidence from patent grant delays. Manage. Sci. 54, 982-997.

Giarratana, M.S., Mariani, M., 2014. The relationship between knowledge sourcing and fear of imitation. Strateg. Manage. J. 35 (8), 1144-1163.

Graham, S.J., Mowery, D.C., 2006. The use of intellectual property in software: implications for open innovation. In: Chesbrough, E.S., Vanhaverbeke, W. West, J. (Eds.), Open Innovation: Researching a New Paradigm. Oxford University Press, New York.

Hagedoorn, J., Ridder, A.-K., 2012. Open innovation, contracts, and intellectual property rights: an exploratory empirical study. UNU-MERIT, Maastricht Economic and Social Research and Training Centre on Innovation and Technology.

Henkel, J., Schöberl, S., Alexy, O., 2014. The emergence of openness: how and why firms adopt selective revealing in open innovation. Res. Policy 43, 879-890.

Henkel, J., 2006. Selective revealing in open innovation processes: the case of embedded Linux. Res. Policy 35, 953-969.

Huang, F., Rice, J., Galvin, P., Martin, N., 2014. Openness and appropriation: empirical evidence from australian businesses. Eng. Manage., 488-498 (IEEE Transactions on 61).

Jensen, P.H., Webster, E., 2009. Knowledge management: does capture impede creation? Ind. Corp. Change 18, 701-727.

Laursen, K., Salter, A.J., 2014. The paradox of openness: appropriability, external search and collaboration. Res. Policy 43 (5), 867-878.

Noordhoff, C.S., Kyriakopoulos, K., Moorman, C., Pauwels, P., Dellaert, B.G., 2011. The bright side and dark side of embedded ties in business-to-business innovation. J. Marketing 75, 34-52.

Nuvolari, A., 2004. collective invention during the British industrial revolution: the case of the Cornish pumping engine. Camb. J. Econ. 28, 347-363.

OECD, 2004. Patents and Innovation Trends and Policy Challenges. Organisation for Economic Cooperation and Development, Paris.

Pérez-Luño, A., Valle-Cabrera, R., 2011. How does the combination of R\&D and types of knowledge matter for patent propensity? J. Eng. Tech. Manage. 28, $33-48$.

Pisano, G., 2006. Profiting from innovation and the intellectual property revolution. Res. Policy 35, 1122-1130.

Stata, 2015. Stata multivariate statistics reference manual. Release, 14.

WIPO, 2007. WIPO Patent Report: Statistics on Worldwide Patent Activities. World Intellectual Property Office, Geneva.

Zobel, A.-K., Balsmeier, B., Chesbrough, H., 2013. Does Patenting Enable or Inhibit Open Innovation?, Last downloaded 02-05-2014 from http://siepr.stanford. edu/system/files/shared/pubs/papers/Patents_OI_Draft_Final.pdf. 